\title{
Studies on the Improvement of Date Palm Productivity Using Different Methods of Pollination and Fruit Thinning Levels
}

Shaaban, M. M. ${ }^{1}$; E. F. S. Ahmed ${ }^{2}$ and M. M. El-Akkad ${ }^{1}$

${ }^{1}$ Pomology Dept., Fac. Agric., Assiut Univ., Assiut, Egypt

${ }^{2}$ Date palm Res. \& Develop. Center Lab., Agric Res. Center, Giza, Egypt

Corresponding Author: Mokhtar M. Shaaban

Pomology Department, Faculty of Agriculture, Assiut University Assiut 71526, Egypt.

Telephone: +20882412831 Cellular: +201001800590 E-mail: mokhshaaban68@hotmail.com

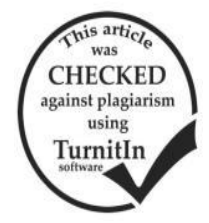

\section{ABSTRACT}

Pollination and thinning are basic procedures of date palms in terms of their impact on fruit development, quality and yield, as well as the organization yearly tree bearing. The development of pollination technology, which leads to an acceptable level of fruit set with the use of small amount of pollen grains and without a further need for thinning, is necessary to improve the productivity of date palms, especially under arid conditions. This examination was done on Saidy date palm for both progressive seasons 2017 and 2018 at El-Kharga Oasis, New Valley Governorate, Egypt. The impact of pollen grain suspension at $0.5,1.0$ and $1.5 \mathrm{~g}$ blended with starch $5.0 \mathrm{~g}$, dust pollen at 10,12.5 and $16.7 \%$ as well as fruit thinning at 10,20 and $30 \%$ on fruit retained, fruit weight/bunch, yield and fruit quality were examined. The outcomes announced that utilization pollen grains suspension at $1.0 \mathrm{~g}+5.0 \mathrm{~g}$ starch and dusting at $10 \%$ as well as the fruit thinning at 30\% had a decrement level of fruit weight/bunch about 9.64, 9.99 and $9.64 \%$ compared to the traditional treatment, respectively. The most elevated estimations fruit weight $(11.28,11.44$ and $11.22 \mathrm{~g})$ were obtained from spraying pollen grains suspension at $0.5 \mathrm{~g}+5.0 \mathrm{~g}$ starch, dusting at $10 \%$ and removing $30 \%$ of fruit, which led to $20.51,22.22$ and $19.87 \%$ increment over the traditional treatment as average of the two seasons, respectively. Likewise, utilizing pollen grains suspension at $0.5 \mathrm{~g}$ or pollen dusting at $10 \%$ and removing $30 \%$ of fruit gave the most elevated values of TSS and sugar contents, while, utilizing the traditional pollination gave the least values. We can conclude from that pollination by either pollen grains suspension at $1.0 \mathrm{~g}$ or dusting at $10 \%$ should be possible to acquire an extensive yield with great quality, increase the efficiency of the pollination process and combine the two methods of pollination and fruit thinning at the same time in their effect on the productivity of date palms.

Keywords: Dusting, Fruit thinning, Fruit quality, pollen spraying, Saidy date palm, Yield

\section{INTRODUCTION}

Date palm (Phoenix dactylifera L.) is a dioecious, perennial, diploid, and monocotyledonous plant (Zhao et al., 2012). It is one of the main crops to grow in the arid lands of most countries of the Middle East and North Africa and affects the high proportion of the economies of these countries (FAO, 2012). Recently, Egypt is a standout amongst the most important countries in the world producing palm trees. Since the date palm is a dioecious crop, the pollination process is carried out by wind or insects, which in turn leads to low-quality fruit. Therefore, to obtain a commercial production, artificial pollination methods must be used (Ghnaim and Al-Muhtaseb, 2006 and El-Salhy et al., 2010). The most imperative yield of date development is a consequence of high fruit set percentage. The achievement of this rate relies upon a blend of a few variables, for example, the quality of the pollen source, the efficiency of the pollination process, the duration of the pollination process, the compatibility of males and females, and environmental conditions such as temperature, irrigation, soil, and fertilization (El-Salhy et al., 2012 and Iqbal et al., 2012).

Building up a pollination procedure and change from the traditional method of pollinator to strategy pollinated by pollen grain-water suspension spray prompted improve the fruit set is perfect degree without thinning process has likewise improved the quality of fruiting attributes. The utilization of the technique for pollinate by pollen suspension with water reduce labor effort and costs of thinning process. Utilizing 0.5 to $2.0 \mathrm{~g}$ of the pollen suspension was sufficient to obtain high yield with good quality (Al-Sabahi et al., 2006; Wad, 2011; Ahmed, 2014). In addition, Al-Wasfy (2014) found that the pollinated by 1.0 to $6.0 \mathrm{~g}$ pollen grains suspension caused expanding yield and fruit quality of Zaghlooul date palm cultivar compared to traditional pollination. Moreover, blending pollen grains with various carriers (dusting or spraying) was beneficial to establish mechanical pollination, acquire a financial yield with great quality and improve pollination effectiveness (Abdel-Galil et al., 2008; El-Salhy et al., 2012; Ahmed, 2014 and Samouni-Mona et al., 2016).

Thinning practices are significant procedures for date palms to improve the size, weight and quality of fruits, just as to decrease the chances of bunch breaking and regulating yearly tree bearing. There are many ways to carry out these operations, such as, for example, bunch or bunch strands thinning and individual fruit removal (ElAssar, 2005; Marashi \& Mousavi, 2007; Mostafa \& ElAkkad, 2011 and Samouni-Mona et al., 2016).

Although several workers have evaluated the effect of different pollination and fruit thinning techniques on fruiting of date palm; the present examination was proposed to assess various methods for pollination and fruit thinning and their potential consequences for yield and fruit quality as for certain physical and chemical characteristics of Saidy date palm under New Valley conditions.

\section{MATERIALS AND METHODS}

The present investigation was executed during two progressive seasons of 2017 and 2018 on Saidy date palms grown on the Research farm of Agricultural Research Station, El-Kharga Oasis, New Valley Governorate, Egypt. Regular agricultural managements were applied to every single test palm as prescribed and pruning was performed to maintain bunch/mature leaves ratio of 1:7. Ten uniform palms of 30 years of age and free of bug harm and maladies were chosen. Ten bunches per palm were 
selected and the rest expelled, each of which was treated as an independent treatment and bunches were diminished to a steady number of strands.

The treatment categories were:

- T1 (splashing pollen grains suspension at $0.5 \mathrm{~g}$ pollen + $5.0 \mathrm{~g} \mathrm{starch} / \mathrm{l})$

- T2 (splashing pollen grains suspension at $1.0 \mathrm{~g}$ pollen + $5.0 \mathrm{~g} \mathrm{starch} / \mathrm{l})$

- T3 (splashing pollen grains suspension at $1.5 \mathrm{~g}$ pollen + $5.0 \mathrm{~g} \mathrm{starch} / \mathrm{l})$

- T4 (dusting pollen grains at 10\% "1 unit of pollen to 9 unit of starch")

- T5 (dusting pollen grains at $12.5 \%$ "1 unit of pollen to 7 unit of starch")

- T6 (dusting pollen grains at $16.7 \%$ "1 unit of pollen to 5 unit of starch")

- T7 (removing 10\% of fruit per strand)

- T8 (removing 20\% of fruit per strand)

- T9 (removing 30\% of fruit per strand)

- T10 (hand pollination by embedding 7-10 strand/bunch)

The pollen grains were separated by expelling protective sheath and the inflorescences were kept under daylight for one hour until pollen grains dried. All splashing and dusting treatments were applied at the third day of spathe cracking as well as fruit thinning treatments were done after fruit set and applied on the same palm. Pollination was performed using one unique pollinator to minimize the occurrence of metazinia. To prevent the mixed between treatments, every bunch was packed by paper bags which are expelled following a month.

\section{Plant measurements}

\section{Yield components}

Initial fruit set and fruit retention percentage were evaluated one month after pollination and at harvest time, respectively. Five female strands per bunch were randomly selected from each replication. The number of fruit and the number of flower scares were recorded and then the fruit set of fruit retention percentage were expressed as following equation:

Fruit set $\%=\frac{\text { No. fruit setting on the strans }}{\text { Total number of flower per strand }} x 100$
Fruit retention $\%=\frac{\text { Number of retained fruits }}{\text { Number of retained fruit }+ \text { number of flower scars }} \times 100$
The total yield/palm $(\mathrm{kg})$ was evaluated at the harvest time and the fruit weight/bunch $(\mathrm{kg})$ was recorded. Fruit quality

Samples of fifteen fruits from each bunch were gathered haphazardly and directly transported to the laboratory for estimate the physical and chemical properties. Fruit weight was measured using an electronic balance just as fruit length and fruit diameter. Total soluble solids (TSS \%) was evaluated using the hand refractometer. Percentage of sugar contents in juice was estimated, according to A.O.A.C. (1990).

\section{Statistical analysis}

The experiment was set up in a complete randomized block design with ten replications of one bunch each. Data were tabulated and statistically analyzed according to Steel and Torrie (1980). Means separation was made according to the Least Significant Differences (LSD) at 5\% level of the probability.

\section{RESULTS}

\section{Yield components}

The perusal of data in Table- 1 demonstrated that all pollination treatments, whether splashed or dusted in addition to fruit thinning, resulted in a significant decrease in the fruit set, fruit retention, as well as the fruit weight/bunch compared to the traditional treatment during the two studies seasons. Also, data showed that the fruit thinning treatments were better than the different pollination treatments in their effect on the fruit retention and fruit weight/bunch. Likewise, the decrement of the fruit weight/bunch was related with diminishing the pollen grains suspension concentration from 1.5 to $0.5 \mathrm{~g}$ pollen, just as dusting pollen from 16.7 to $10 \%$ and expanding the fruit thinning level from 10 to $30 \%$. There was no significant difference in the fruit retention and fruit weight/bunch due to pollination either by splashing with pollen grains suspension at $1.0 \mathrm{~g}+5.0 \mathrm{~g}$ starch and dusting at $10 \%$ or the fruit thinning at $30 \%$. The decrement of fruit weight/bunch were $9.64,9.99$ and $9.64 \%$ (as average of the two seasons) compared to the traditional treatment, respectively.

Table 1. Impact of different pollination methods and fruit thinning levels on fruit set, fruit retention and fruit weight/bunch of Saidy date palm during 2017, 2018 seasons.

\begin{tabular}{lccccccccc}
\hline \multirow{2}{*}{ Treatment } & \multicolumn{3}{c}{ Fruit set \% } & \multicolumn{3}{c}{ Fruit retention \% } & \multicolumn{3}{c}{ Fruit weight/bunch (kg) } \\
\cline { 2 - 10 } & $\mathbf{2 0 1 7}$ & $\mathbf{2 0 1 8}$ & Mean & $\mathbf{2 0 1 7}$ & $\mathbf{2 0 1 8}$ & Mean & $\mathbf{2 0 1 7}$ & $\mathbf{2 0 1 8}$ & Mean \\
\hline Splashing(0.5g pollen) & 53.69 & 55.70 & 54.70 & 49.68 & 50.39 & 50.04 & 9.88 & 10.00 & 9.94 \\
Splashing (1.0g pollen & 57.85 & 58.17 & 58.01 & 52.87 & 52.60 & 52.74 & 10.10 & 10.52 & 10.31 \\
Splashing(1.5g pollen) & 61.83 & 63.69 & 62.76 & 53.92 & 55.93 & 54.93 & 10.20 & 10.61 & 10.41 \\
Dusting(10\% pollen) & 56.67 & 58.36 & 57.52 & 50.22 & 51.82 & 51.02 & 10.00 & 10.54 & 10.27 \\
Dusting(12.5\% pollen) & 62.28 & 64.10 & 63.19 & 54.39 & 56.11 & 55.25 & 10.45 & 10.85 & 10.65 \\
Dusting(16.7\% pollen) & 71.98 & 72.24 & 72.11 & 58.22 & 58.67 & 58.45 & 10.38 & 10.81 & 10.60 \\
Removing(10\% fruits) & 86.10 & 85.83 & 85.97 & 69.35 & 68.68 & 69.02 & 10.58 & 10.93 & 10.76 \\
Removing (20\% fruits) & 83.85 & 84.90 & 84.38 & 59.63 & 60.10 & 59.87 & 10.28 & 10.80 & 10.54 \\
Removing (30\% fruits) & 85.11 & 84.35 & 84.73 & 54.68 & 52.83 & 53.76 & 10.10 & 10.51 & 10.31 \\
Hand pollination & 85.18 & 87.23 & 86.21 & 72.81 & 72.11 & 72.46 & 11.18 & 11.63 & 11.41 \\
\hline L.S.D. at 5\% & 4.22 & 3.69 & \multicolumn{3}{c}{3.37} & 3.18 & & 0.76 & 0.81 \\
\hline
\end{tabular}

It tends to be closed from these outcomes that, the utilization of splash treatments reduce the measure of pollen to 0.1 from the amount used by dusting and this portion insignificantly affected fruit retention or yield. On the other means, pollination with pollen grains dust needs to centuple pollen grain amount that pollination as pollen 
grain suspension spraying. Consequently, pollen grain suspension prompts increment the pollination efficiency, decline utilization of pollen grains and diminish the pollination costs.

Fruit quality

Physical characteristics

As shown in Table-2 there was an improvement of the fruit physical quality in terms of expanding the fruit weight, size and pulp percentage and reducing moisture content due to pollination techniques either splashing pollen grains suspension or dusting pollen, just as fruit thinning compared to the hand pollination treatment (control). The most elevated estimations fruit weight (11.28, 11.44 and $11.22 \mathrm{~g})$ were obtained from splashing pollen grains suspension at $0.5 \mathrm{~g}+5.0 \mathrm{~g}$ starch, dusting at $10 \%$ and removing $30 \%$ of fruits, which led to 20.51 ,
22.22 and $19.87 \%$ increment over the control as average of the two seasons, respectively. No significant difference in the fruit weight or size were observed due to splashing pollen grains suspension at 0.5 or $1.0 \mathrm{~g}$ and dusting at 10 or $12.5 \%$ as well as removing 20 or $30 \%$ of fruits. Furthermore, the lowest value of fruit moisture percentage were $13.09,12.87$ and 12.95 for splashing pollen grains suspension at $1.5 \mathrm{~g}+5.0 \mathrm{~g}$ starch, dusting at $10 \%$ and removing $30 \%$ of fruits, which prompted a decrement of $9.22,10.75$ and $10.19 \%$ less than the control as average of the two seasons, respectively. The expansion in the fruit weight and its size and diminishing the fruit moisture content are the most significant target than all-out yield due to prompt an increment the packable yield and raise the cost.

Table 2. Impact of different pollination methods and fruit thinning levels on fruit weight, size and fruit moisture percentage of Saidy date palm during 2017, 2018 seasons.

\begin{tabular}{lccccccccc}
\hline \multirow{2}{*}{ Treatment } & \multicolumn{3}{c}{ Fruit weight $(\mathbf{g})$} & \multicolumn{3}{c}{ Fruit size $\left(\mathbf{c m}^{\mathbf{3}}\right)$} & \multicolumn{3}{c}{ Fruit moisture \% } \\
\cline { 2 - 10 } & $\mathbf{2 0 1 7}$ & $\mathbf{2 0 1 8}$ & Mean & $\mathbf{2 0 1 7}$ & $\mathbf{2 0 1 8}$ & Mean & $\mathbf{2 0 1 7}$ & $\mathbf{2 0 1 8}$ & Mean \\
\hline Splashing(0.5g pollen) & 11.18 & 11.38 & 11.28 & 11.59 & 11.82 & 11.71 & 13.13 & 13.25 & 13.19 \\
Splashing (1.0g pollen & 10.93 & 11.10 & 11.02 & 11.22 & 11.34 & 11.28 & 13.46 & 13.22 & 13.34 \\
Splashing (1.5g pollen) & 10.62 & 10.80 & 10.71 & 10.61 & 10.94 & 10.78 & 13.18 & 13.00 & 13.09 \\
Dusting(10\% pollen) & 11.57 & 11.31 & 11.44 & 11.99 & 11.65 & 11.82 & 12.85 & 12.88 & 12.87 \\
Dusting(12.5\% pollen) & 11.68 & 11.10 & 11.39 & 11.93 & 11.56 & 11.75 & 12.90 & 13.00 & 12.95 \\
Dusting(16.7\% pollen) & 10.48 & 10.66 & 10.57 & 10.87 & 11.15 & 11.01 & 13.25 & 13.18 & 13.22 \\
Removing (10\% fruits) & 10.35 & 10.21 & 10.28 & 10.76 & 10.63 & 10.70 & 13.35 & 13.40 & 13.38 \\
Removing (20\% fruits) & 11.08 & 10.93 & 11.01 & 11.42 & 11.32 & 11.37 & 13.50 & 13.21 & 13.36 \\
Removing (30\% fruits) & 11.15 & 11.28 & 11.22 & 11.48 & 11.63 & 11.56 & 13.00 & 12.89 & 12.95 \\
Hand pollination & 9.28 & 9.43 & 9.36 & 9.48 & 9.73 & 9.61 & 14.38 & 14.45 & 14.42 \\
\hline L.S.D. at 5\% & 0.48 & 0.53 & & 0.58 & 0.70 & & 0.58 & 0.61 & \\
\hline
\end{tabular}

\section{Chemical characteristics}

The pollination with pollen grains suspension or dusting, just as fruit thinning were essentially enhanced the fruit chemical constituents regarding expanding the total soluble solids (TSS) and sugar contents contrasted with the control (Table-3). The improvements of these fruit characteristics were related with the reduction of pollen grains suspension from 1.5 to $0.5 \mathrm{~g}$ and dusting from 16.7 to $10 \%$ just as increment the fruit thinning from 10 to $30 \%$. Utilizing pollen grains suspension at $0.5 \mathrm{~g}$ or pollen dusting at $10 \%$ and removing $30 \%$ of fruit gave the most astounding estimations of TSS and sugar contents, while, utilizing the traditional pollination gave the lowest values. No significant differences in fruit chemical properties were observed among the different pollination techniques or fruit thinning levels.

Table 3. Impact of different pollination methods and fruit thinning levels on fruit chemical properties of Saidy date palm during 2017, 2018 seasons.

\begin{tabular}{lccccccccc}
\hline \multirow{2}{*}{ Treatment } & \multicolumn{3}{c}{ TSS \% } & \multicolumn{3}{c}{ Total sugar \% } & \multicolumn{3}{c}{ Reducing Sugar \% } \\
\cline { 2 - 10 } & $\mathbf{2 0 1 7}$ & $\mathbf{2 0 1 8}$ & Mean & $\mathbf{2 0 1 7}$ & $\mathbf{2 0 1 8}$ & Mean & $\mathbf{2 0 1 7}$ & $\mathbf{2 0 1 8}$ & Mean \\
\hline Splashing (0.5g pollen) & 80.14 & 81.90 & 81.02 & 72.13 & 73.28 & 72.71 & 63.78 & 64.15 & 63.97 \\
Splashing (1.0g pollen & 79.10 & 81.78 & 80.44 & 71.94 & 73.27 & 72.61 & 63.68 & 64.10 & 63.89 \\
Splashing (1.5g pollen) & 78.91 & 81.63 & 80.27 & 71.81 & 73.10 & 72.46 & 63.64 & 64.81 & 64.23 \\
Dusting(10\% pollen) & 81.52 & 83.78 & 82.65 & 73.68 & 74.92 & 74.30 & 65.17 & 65.35 & 65.26 \\
Dusting(12.5\% pollen) & 80.38 & 82.93 & 81.66 & 73.74 & 74.68 & 74.21 & 65.36 & 65.14 & 65.25 \\
Dusting(16.7\% pollen) & 79.39 & 82.18 & 80.79 & 72.25 & 73.60 & 72.93 & 63.95 & 64.36 & 64.16 \\
Removing (10\% fruits) & 80.00 & 82.60 & 81.30 & 72.89 & 73.94 & 73.42 & 64.27 & 64.38 & 64.33 \\
Removing (20\% fruits) & 80.11 & 82.54 & 81.33 & 72.89 & 73.80 & 73.35 & 64.10 & 64.24 & 64.17 \\
Removing (30\% fruits) & 81.38 & 83.49 & 82.44 & 74.10 & 74.38 & 74.24 & 65.24 & 64.73 & 64.99 \\
Hand pollination & 76.35 & 78.63 & 77.49 & 69.22 & 70.12 & 69.67 & 61.63 & 62.18 & 61.91 \\
\hline L.S.D. at 5\% & 2.45 & 2.68 & & 2.38 & 2.65 & & 1.95 & 1.82 & \\
\hline
\end{tabular}

\section{DISCUSSION}

The results declared that use pollen grains suspension at $1.0 \mathrm{~g}+5.0 \mathrm{~g}$ starch and dusting at $10 \%$ or the fruit thinning at $30 \%$ had a decrement level of fruit weight/bunch about $9.64,9.99$ and $9.64 \%$ compared to the traditional treatment, respectively. The most elevated estimations fruit weight $(11.28,11.44$ and $11.22 \mathrm{~g})$ were obtained from spraying pollen grains suspension at $0.5 \mathrm{~g}+$ $5.0 \mathrm{~g}$ starch, dusting at $10 \%$ and removing $30 \%$ of fruit, 
which led to $20.51,22.22$ and $19.87 \%$ increment over the traditional treatment as average of the two seasons, respectively. Additionally, using pollen grains suspension at $0.5 \mathrm{~g}$ or pollen dusting at $10 \%$ and removing $30 \%$ of fruit gave the most elevated vales of TSS and sugar contents, whereas, using the hand pollination gave the least values.

The reduction on fruit weight/bunch and subsequently the yield/palm was related with diminishing the pollen grain concentration whatever utilizing spraying suspension or dusting just as expanding the fruit thinning level. This finding can be attributed to the decrease of fruit retention, which thus is reflected in the low number of fruits/bunch and consequently the fruit weight/bunch. Furthermore, the abatement of fruit set causes a reduction in the number of fruits per bunch without changing the quantity of leaves that may initiate a superior supply of carbohydrates that are synthesized in the leaves. Accordingly, the decrease in fruit was effective on bringing down the challenge among the fruits and induce a sufficient carbohydrate and other essential assimilated for the residual ones consequently, improve the fruit physical properties, enhance the fruit maturity and improve its contents of total soluble solids and sugar. Also, the utilization of pollen grains suspension or dusting plays a joined mechanical pollination and fruit thinning impacts. These outcomes are in close similarity with the discoveries of Alabri et al., 2006; Nirmaljit et al., 2006; Khayyat et al., 2007; Marashi \& Mousavi, 2007;Ashour et al., 2008; Iqbal et al., 2010; Abdalla et al., 2011; El-Salhy et al., 2012; Damankeshan \& Panahi, 2013; Bashir et al., 2014; AlSaikhan \& Sallam, 2015 and Samouni-Mona et al., 2016.

\section{CONCLUSION}

Pollination of Saidy date palm utilizing pollen grains suspension at $1.0 \mathrm{~g}+5.0 \mathrm{~g}$ starch/L or pollen grain dusting at $10 \%$ was adequate to get a high yield with great quality. Besides, since the amount of pollen grains utilized is lower and less labor is required in mechanical pollination, it is increasingly efficient techniques and increment the pollination efficiency compared to hand pollination.

\section{REFERENCES}

Abdalla, M.G., A.M. EL-Salhy and R.A.A. Mostafa (2011). Effect of some pollination treatments on fruiting of Zaghloul date palm cultivars under Assiut climatic conditions. Assiut J. of Agric. Sci., 42: 350-362.

Abdel-Galil, H.A., A.M. El-Salhy, M.M. El-Akkad and Y.M. Diab (2008). Effect of different methods and dates of fruit thinning on "Sewy" date yield and quality under New Valley conditions. The $3^{\text {rd }}$ Int. Conf. on Date Palm, 25-27 April, El-Arish, Egypt.

Ahmed, E.F.S. (2014). Increasing pollination efficiency in Saidy date palms using starch carrier along with pollens suspension. Proceeding of the $5^{\text {th }}$ International Date Palm Conference, Abu Dhabi, UAE, March 16-18, p. 237-243.
Alabri, N., K. Al-Busaidi and S. Alhemaimee (2006). Effect of pollen grains suspension on fruit set and physicochemical characteristics of two date palm (Phoenix dactylifera.) cultivar Qnt. Conf. on date palm production and processing technology Muscat, Oman, May 9-11, P 19.

Al-Sabahi, S., K. Al_Busaidi, S. Al-Amree and S. Al-Abri (2006). Effect of pollen grains suspension on fruit set and yield of date palm (Phoenix dactylifera) cultivar Fard. Conf. on date palm production and processing technology, Muscat, Oman, May 9-11, p 18.

Al-Saikhan, M.S. and A.A. Sallam (2015). Impact of chemical and non-chemical thinning treatment on yield and fruit quality of date palm. J. of Food and Research, 4, 4: 18-24.

Al-Wasfy. M.M.M. (2014). Yield and fruit quality of Zaghloul date palm in relation to using new technique of pollination. Stem Cell, 5, 1: 14-17.

Ashour, N.E., H.S.A. Hassan and E.A.M. Mostafa (2008). Effect of some pollen carriers on yield and fruit quality of Zaghloul and Samani date palm cultivars. American-Eurasian J. Agric. \& Environ. Sci., 4, 3: 391-396.

Association of Official Agricultural Chemicals (A.O.A.C.), (1990). Official Methods of Analysis of the A.O.A.C., $15^{\text {th }}$ Ed. Published by A.O.A.C. Washington D.C., USA.

Awad, M.A. (2011). Pollination of date palm (Phoenix dactylifera L. Lulu) with pollen grains water suspension. Met., Env. \& Arid Land Agric. Sci., 22, 1: 91-99.

Bashir, M.A., M. Ahmad, F. Altaf and K. Shabir (2014). Fruit quality and yield of date palm (Phoenix dactylifera L.) as affected by strand thinning. J. Anim. Plant Sci., 24, 3: 951-954.

Damankeshan, B. and B. Panahi (2013). Evaluation of the effects of bunch thinning methods on drying blossom of date palm disorder in two stages of pollination and Kimri. Inter. Res. of Appl. Basic. Sci., 4, 6: 1514-1516.

El-Assar, A.M. (2005). Response of "Zaghloul" date yield and fruit characteristics to various organic and inorganic fertilization types as well as fruit thinning models in a rich carbonate soil. J. Agric. Sci. Mansoura Univ., 30, 5: 2795-2814.

El-Salhy, A., H.A. Abdel-Galil, A.A. El-Bana and E.F. Ahmed (2010). Effect of pollen grains suspensions spraying on yield and fruit quality of Saidy date palm cultivar. Acta Horti. 882: 329-336.

El-Salhy, A.M., R.A.A. Mostafa, A.A. El-Banna and Y.M. Diab (2012). Effect of pollination methods and pollen grains dilution on bunch weight and fruit quality of Sewy date palm cultivar. Assiut J. Agric. Sci., 43, 2: 119-131.

Food and Agriculture Organization "FAO" (2012). Food and Agriculture Organization Statistical Year Book, FAO. Rme Italy.

Ghnaim, H.D. and J.A. Al-Muhtaseb (2006). Effect of pollen source on yield, quality and maturity of "Mejhool" date palm. Jordan Journal of Agricultural Sciences 2: 8-15. 
Iqbal, M., M. Niamatullah and M. Munir (2012). Effect of various Dactylifera males pollinizer on pomological traits and economical yield index of cv's Shakri, Zahidi and Dhakki date palm (Phoenix dactylifera L.). J. Anim Plant Sci. 22: 376-383.

Iqbal, M., M.Q. Khan., M. Munir, S.U. Rehmn, H.U. Rehman and M. Niamatulllah. (2010). Effect of different pollination techniques on fruit set, pomological characters and yield of Dhakki date (Phoenix dactylifera L.) in Dera Ismail Khan, KP. Sarhad J. Agric., 26, 4: 515-518.

Khayyat, M., E. Tafazoli, S. Eshaghi and S. Rajaee (2007). Effect of nitrogen, boron, potassium and zinc sprays on yield and fruit quality of date palm. American Eurasian J. Agric. \& Environ. Sci., 2, 3: 289-296.

Marashi, S. and A. Mousavi (2007). Effect of different methods and degrees of fruit thinning on yield and fruit characteristics of Barhee date cultivar. Acta Hort. (ISHS) 736: 187-192.
Mostafa R.A.A. and M.M. El Akkad (2011). Effect of fruit thinning rate on yield and fruit quality of Zaghloul and Haiany date palms. Australian J. of Basic and Applied Sciences, 5, 12: 3233-3239.

Nirmaljit, K., J.S. Josan and P.K. Monga (2006). Fruit thinning of dates in relation to fruit size and quality. Proceeding of the $3^{\text {rd }}$ International Date Palm Conf., Abu Dhabi, UAE, Feb. 19-21.

Samouni-Mona, T.M., A.M. El-Salhy, Ibtesam F.M. Badawy and E.F. Ahmed (2016). Effect of Pollination and Thinning Methods on Yield and Fruit Quality of Saidy Date Palms. Assiut J. Agric. Sci., 47, 3: 92-103.

Steel, R.G., and J.H. Torrie (1980). Principles and procedures of statistics $2^{\text {nd }}$ Ed. Mc. Graw Hill Book Company, New York, USA pp. 183-193.

Zhao, Y., R. Williams, C.S. Prakash and G. He (2012). Identification and characterization of gene-based SSR markers in date palm (Phoenix dactylifera L.). BMC Plant Biol 12: 237.

\footnotetext{
دراسات على تحسين إنتاجية نخيل البلح باستخلام طرق ومستويات مختلفة للتلقيح وخف الثمار

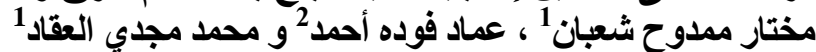

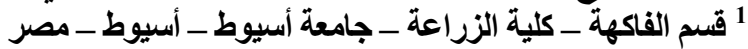

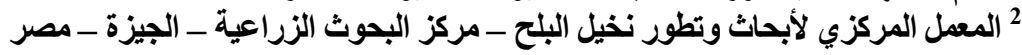

تعتبر عمليات التلقيح وخف الثمار من العمليلا البستانية الأساسية في نأثير ها على نخيل البلح من حيث النأثير على نمو الثمار وجودتها

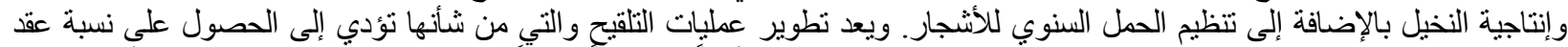

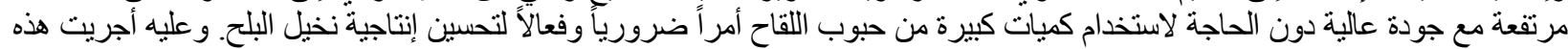

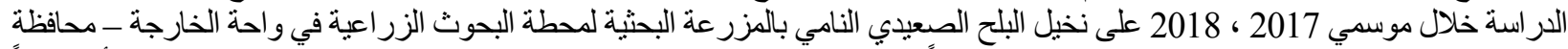

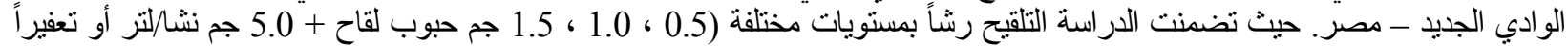

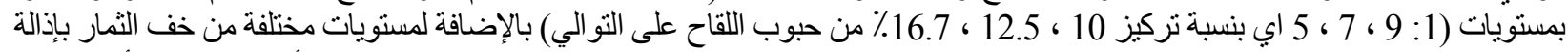

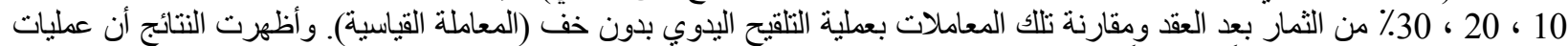

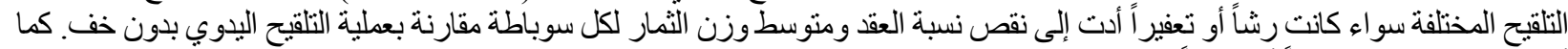

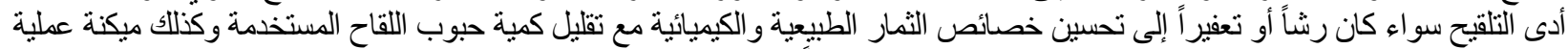

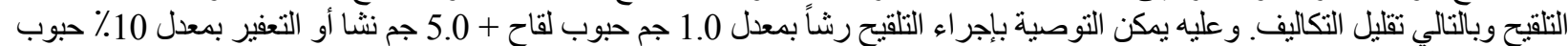

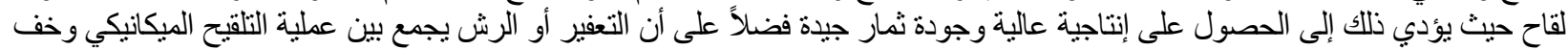
الثمارمع تقليل كمية حبوب اللقاح المستخمة مما يقلل من تكلفة الإنتاج وتحسين كفاءة التلقيح وتحسن خصائص التص الثمار.
} 